\title{
FUNCTIONAL ASPECTS OF MODERN AND ANCIENT PEDESTRIAN MOBILITY ON HISTORIC STONE PAVEMENTS
}

\author{
E. CEPOLINA ${ }^{1}$, A. MARRADI ${ }^{1} \&$ D. ULIVIERI $^{2}$ \\ ${ }^{1}$ Department of Civil and Industrial Engineering, University of Pisa. \\ ${ }^{2}$ Department of Civilisations and Forms of Knowledge, University of Pisa.
}

\begin{abstract}
Walking is a fundamental human activity and is an essential component in sustainable transport: it is a viable alternative to private and public transport, in case of short trips, and it also plays a key role in the public transport mode, since public transport is a transport inter-modal chain where the foot journeys have an important weight. Besides, walking is an ancient and natural act, it has always been connected with open space, but the same action of walking brought up, at least until the first half of the 18th century, considerable difficulties. The ability to use public spaces with facility and freedom was enjoyed in different ways depending on gender and social class. The stylistic and typological differences between men's and women's shoes, between shoes worn by people belonging to low and high rank determined over the centuries different mobility patterns. The ability to walk is connected with the type of the road surface and with the structure of the shoe that changes over the centuries as the concept of walking is changing. The road networks of inner city centers and the topic of the historic pavements to the same degree express the historical image of a place as the colors of the facades on buildings overlooking the streets. The paper aims to explore safety for pedestrian mobility in the present and in the past. With reference to stone pavements, it focuses on the analysis of all the properties that affect safety, particularly in terms of roughness, texture and skid resistance. Friction in dry and wet conditions will be analyzed taking into account different types of shoes, used both in the past and in the present time. The paper ends with remarks about safety for pedestrian mobility, specifically addressed to the historical city centre of Volterra, Tuscany, Italy.
\end{abstract}

Keywords: historic stone pavements, pedestrian mobility, Tuscany, Volterra.

\section{INTRODUCTION}

Most of the European historical city centers are characterized by stone road pavements that have been hereditated from the medieval period. The particular characteristics of these road pavements are an important historical value, which has been preserved until today despite the new need for speed and endurance. On these roads, footways are absent and the road is shared by pedestrians and vehicles now as it was in the past. In the past, the roads were mainly used by carriage transport and less by pedestrians now it is the other way round. Road pavements have been preserved across the centuries thanks to maintenance. Conversely, the material in contact with the pavement surface changed a lot in time. The cart wheels were made of wood with a band of iron around the outside rim, now vehicle wheels are tires. The soles of shoes were made by cork or wood or leather, and they were extremely rigid due to the thickness. Now shoes have very often flexible soles made with natural rubber or newer materials and often have spikes embedded in the outsole to improve traction. The paper has been structured mainly in two parts. The first part presents an historical analysis (from the Medieval age until 
the present time) about stone road pavements and mobility materials in the urban centers of the Tuscany region. Specifically, Chapter 2 investigates Towns councils' commitments to the maintenance and construction of roads that, from the Middle Ages, translated into an increase in statutory provisions on the subject. Chapter 3 analyzes the wheeled transportation and pedestrian mobility: leather, wooden or cork shoes, animal's hooves and iron-rimmed cartwheels criss-crossed the Tuscan stone paved roads until the early 20th century; also, the chapter considers the shoes with rubber or leather soles and tires. The ability to move is therefore linked to the type of road surface and the structure of the footwear, which changes over the centuries.

From here came the idea to launch a series of experimental investigations into the specific slip resistance tests on as laid down in standard UNI EN 14231/2003 on Volterra panchina stone (samples 1, 2 and 3) for the purpose of assessing the validity of local experience. The results of these investigations are set out in Chapter 4.

\section{WITH REGARD TO “THE VERY USEFUL WAY OF PAVING THE ROADS”: GOVERNMENT REGULATIONS AND MUNICIPAL BY-LAWS}

In Tuscany, however, 'surfacing the roads with stone slabs' was an ancient custom. After all, paving is nothing more than 'a covering of stones laid flat on the ground for ease of walking'. As early as the XIII century, 'the very useful way of paving roads' was introduced in Florence [1].

The use of paving stones was, however, limited to urban areas, and particularly to those public roads which were most heavily trafficked and subject to the greatest wear and tear. Less busy minor roads, on the other hand, were cobbled or more often unpaved. Andrea Palladio takes care to distinguish 'the place where men walk from that which serves for the use of carts and animals', and states that it is good working practice to pave the edges of the road with bricks 'because walking on it does not harm the foot at all' [2].

Then again, the iron-rimmed wheels of carts needed paved, well-connected roads. On dirt roads, especially if muddy, they risked getting bogged down and even breaking.

Moreover, stone material is worn smooth 'by long, incessant friction from animal hooves and the wheels of vehicles' [3]. Too smooth stone slabs, steep slopes and bitter winter weather put the poor pedestrians and the animals in serious danger as they constantly risked falling.

However, the serious problem of constant road maintenance weighed on the community, and archival records are full of continual complaints by inhabitants about the damage caused by carts to the paving.

The paving of roads was an art form worthy of respect, to the extent that in 1681 Filippo Baldinucci included the entry "Lastricato e Lastrico" in the famous Tuscan Dictionary of Art and Design [4].

At the end of the XVI century, as a result of the growing interest in the policy of urban paving, specific roles such as 'Road Agent' and 'Paving Commissioner' were added to the body of experts.

Towns councils' commitments to the maintenance and construction of roads and bridges also translated into an increase in statutory provisions on the subject. In fact, from the Middle Ages, regulations relating to waterways and roads were one of the most important aspects of the various legal systems. Medicean legislation employed the provisions established in 14th and 15 th century regulations, and the rules continued in almost identical form until the second half of the 18th century. The grand-ducal laws, the enormous body of statutes governing the cities and territorial communities overlapped, and often 'legislation on the environment was entrusted to local statutory law' [5]. 
From the 17 th century, probably simultaneously with growing use of the cart, regulations regarding 'repaving or restoring' the streets of the town multiplied, obliging the owners of 'Houses, Shops and other properties' facing onto the stretch of road to be paved to pay their share of the expense.

To try to preserve the road surface, Grand-Duchy laws and town by-laws prohibited carts with 'nail studded iron-rimmed wheels' from crossing the towns, but it is obvious that the stagnant water also damaged the paving by penetrating into fissures and splitting apart the stones.

At least until the end of the 17th century, the laws did not include detailed technical information about the paving of roads. This already centuries-old practice in Tuscany had not been codified in writing since in reality there had never been the need to do so.

After all, the skilled tradesmen based themselves on direct observation. Their knowledge was not written but founded on local experience, the method was experimental. Therefore, best working practices already implicitly contained all the instructions and checks. According to Leon Battista Alberti, the paving stones should be neither too big nor too small 'to the point where the animals slip on them'. The quality of the stone is important, explains Alberti. Indeed, the material wears down 'due to friction from animals' hooves and the wheels of the vehicles'. After all 'even the friction from ants' feet ends up furrowing a path in paving stones'. "Indeed, the ancients preferred stone paving [...] because it is less slippery for those walking on it" [3].

During his visit to Florence in 1786, the erudite and noble Neapolitan Giovan Battista Malaspina noted that despite the paving being 'comprised of large oblong stones, very comfortable for pedestrians', the good practice of 'tapping the stones with a chisel, since their smoothness can only be dangerous in the rain' had been completely abandoned [6].

In Volterra the regulations for carrying out road paving works insist on the dimensions of the blocks of panchina stone, chosen 'without veining, cavities or other imperfections', the thickness and the finishes. The stones for new lastricato had to be no less than $50 \mathrm{~cm}$ long, $40 \mathrm{~cm}$ wide and $18 \mathrm{~cm}$ thick. Stones for new selciato, instead, had to be no less than $25 \mathrm{~cm}$ per side by $10 \mathrm{~cm}$ thick. All stones, whether new or old, had to be rough surfaced and re-rough surfaced in order to prevent the surface from becoming smooth and dangerous.

In the first decades of the 19th century, the training of engineers and architects began to be disciplined. In 1826, the regulations for the new corps of engineers approved by Grand Duke Leopold II was edited and published in Florence. According to the fifth section of the regulations every engineer should 'always observe the results of local experience'. By virtue of this approach, which continued until the end of the 19th century and beyond, Tuscany demonstrated a technical and professional culture that observed, tested and interacted with the local building culture.

The Regulations of the Engineering Corps included a section headed Lastrici e selciati, consisting of detailed standards which integrated and codified the empirical basis of valuable local experience. The systems recommended by municipal engineers for maintenance of the paving included technical directions that already formed part of the cultural baggage of stonemasons and specialized tradesmen.

Best working practices relating to Lastrici e Selciati included provisions regarding the construction of new Lastrici and Selciati, and the 'Restoration and Patching' of material worn smooth at the points of greatest friction by rough finishing the surface.

The best practices codified by Nineteenth century engineers are the same ones followed by masons and specialized tradesmen, such rules being the result of a series of practical experiments. 
Even if in Pietro Leopoldo's time, in agreement with scientists' considerations regarding public health, an attempt was made to regulate management of the inland roads and those of local interest, by then reduced to inaccessible mule tracks, in the wake of the Restoration, the general condition was substantially identical. The roads in towns were dirty; paving, if present, was covered with mud and filthy, evil smelling water; sidewalks were very rare and rubbish spread everywhere. Until the time when it became compulsory to construct cess pits, that is, from the first half of the 19th century, effluent from homes, stables, carriage houses and other even dirtier water was thrown directly into the street and the drains, which regularly became blocked.

\section{MOBILITY MATERIALS: WHEELS, HOOFS AND SHOES, CHOPINES AND LEATHER-SOLED STOCKINGS}

During the early Middle Ages, wheeled transportation increased, but it was never as important as shipping by water during the period. Its importance was mostly local and personal, in the form of simple carts. Wagons and carts allowed heavy objects to be moved easily facilitating movement or transportation while supporting loads. As in Roman times, oxen still pulled the very heavy wagons.

The wagons were of either a two-wheeled or a four-wheeled variety. The two-wheeled cart was much more common the four-wheeled. Two-wheels sufficed to carry the load, a twowheeld cart was easier to maneuver on a deeply rutted road or track.

The wheels contain either 8 or 12 spokes. Iron banding of wheels which was common during the Roman Empire also appears to have been lost to the Middle Ages. In the late Middle Ages, the majority of wagon wheels were still without metal banding [7].

Additional nails, left sticking out a bit, could give the wheels more traction. All through the Middle Ages, the earlier technique of nailing wooden strakes around the wheel remained very popular. Wheels properly attached to a cart or a wagon were set at an angle to counterbalance the swaying of the animal's movement, the shifting of the load, and especially the uneven road surface.

In winter or in very steep places where more friction with the ground was helpful, sledges were also used [8].

From the Middle Ages, pedestrian mobility was also subjected to a series of limitations imposed by physical factors such as the absence of sidewalks and the awful state of the roads. The skill to use public spaces with facility and freedom was enjoyed in a different way and depended on gender and on social class of people. The stylistic and typological differences between men's shoes and women's shoes, including shoes for feet of low social status and shoes for feet of high rank determined over the centuries different mobility patterns [9].

If the shoe is the interface between the human body and physical space, the ability to move on foot is therefore linked to the type of road surface and the structure of the footwear, which changes over the centuries like the concept of walking itself.

In the latter centuries of the Middle Ages, men and women, rich and poor, usually wore cork or wooden pattens as protection against the mud and dirt of the town streets. Pattens, usually made from walnut, elm or plane tree wood, had a low or high sole and a simple leather band across the foot. Until the beginning of the XVIII century, we still find pattens with a double elevation, one under the heel and one at mid-foot, which would give way to the use of an increasingly high, slender heel [10].

So if the sidewalk can be considered the lifeline from the bog of the road, the patten is no less than its forerunner. Baldinucci explains that the patten is a type of shoe 'similar to the 
chopine but with a wooden sole notched in the middle of the part that rests on the ground, made to elevate the foot and keep it above the wetness of the ground' [4].

In the XIV century, a new type of shoe began to be made, called chapins in Spanish and French, chopines in English and pianelle in Italian, with a leather or fabric upper and a wooden or light cork sole. Chopines, therefore, were nothing more than the product of a gradual transformation of the patten [11].

At least originally, chopines were 'outdoor' shoes open behind the heel, with a cork sole for lightness, and were worn by men and women alike. But while the chopines worn by men had a platform just a few centimetres high, those worn by women could reach dizzying heights (from about $20 \mathrm{~cm}$ to half a metre), Fig. 1. Men often wore knee-length boots, or 'soled stockings', that is, with a thick leather reinforcement under the sole of the foot, Fig. 1.

In the chopines, the wedge at the front of the sole gave women a very particular unstable gait, which contributed to the differentiation of gender and recognition of the wearer's high social standing. High chopines, 'shoes with long pointed toes', shoes with square toes, tight, pointed sandals and shoes decorated with ermine certainly did nothing to make it easy for women to walk on roads that were for the most part rutted, impassable and often sloping. The Florentine chopines had a wooden wedge shaped in varied forms. The wooden sole in the stone pavement was what produced the 'trich trach of the slippers' recalled by Piccolomini in relation to women who have the bad habit of walking too fast 'so that it seems they have the devil between their legs' [12].

Women especially were subject to regulations, the so-called 'sumptuary laws', which disciplined the manner of dressing, forbidding the use of particular types of shoe, at times limiting their height and sometimes prohibiting the use of certain materials. From the mid XIII to the end of the XVIII centuries, sumptuary laws attempted to regulate dress, making it above all a matter of gender and social class. The case of the chopine is somewhat emblematic; venerated by women and despised by preachers and by legislators who proposed they should be of simple leather or cloth, no more than four digits high (equivalent to eight centimetres), and unadorned, without lace, jewels or gold or silver decoration.

If on one hand confessors and preachers considered the 'planellas altas' instruments of ambiguity, on the other, although to a lesser degree, law-makers were concerned with limiting their height for safety reasons, that is, to reduce the frequent disastrous falls, fractures, and in some cases, miscarriages [13].

As early as the 14th century in Florence, the height of chopines was established by law and limited to about $8 \mathrm{~cm}$.
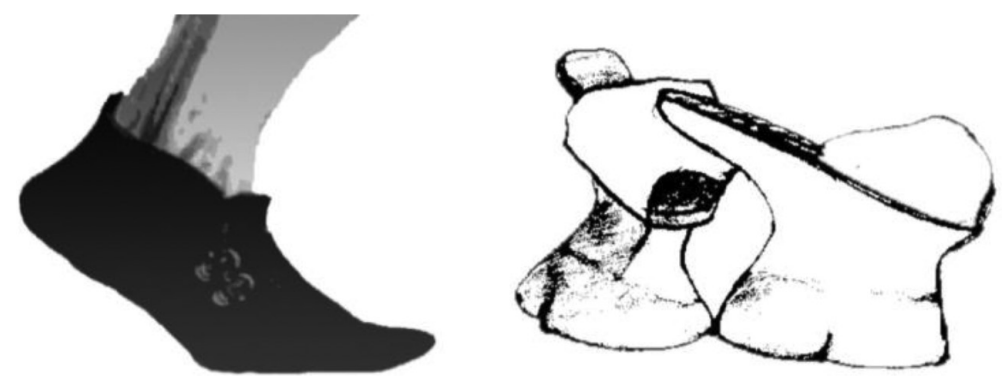

Figure 1: Scarpette and high chopines. 
At the end of the 17th century, the mania for chopines was in decline, probably because of the rise of a smaller, more delicate type of shoe. During the 18th century, women's shoes with fabric uppers were so delicate that they were protected by pattens or overshoes to insulate them from the rain and dirt.

Men's shoes, though, were more robust and practical, made entirely of leather and not very different from those of today. Working class women, on the other hand, continued to wear leather shoes similar to those of men. The common man wore leather or cloth leggings and well-worn shoes protected by pattens [9].

During the 19th century, transformation of urban spaces, the fall of many physical barriers and new theories about individual health contributed to improving freedom of movement, especially for men. Women, on the other hand, still had few opportunities for contact with the outside world, and their journeys on foot were limited to short routes within the urban space.

Since the mid-20th century, advances in rubber, plastics, synthetic cloth, and industrial adhesives have allowed manufacturers to create shoes that stray considerably from traditional crafting techniques. Leather, which had been the primary material in earlier styles, has remained standard in expensive dress shoes. Soles, which were once laboriously handstitched on, are now more often machine stitched or simply glued on. Most modern shoes have soles made from natural rubber and newer materials like polyurethane, or polyvinyl chloride (PVC) compounds. Often modern shoes have spikes embedded in the outsole to improve traction.

\section{EXPERIMENTAL INVESTIGATIONS}

According to $\mathrm{Lu}$ and Steven [14], pavement friction depends on both the microtexture of aggregates and the macrotexture of the overall pavement surface. Microtexture, usually defined as small-scale texture up to $0.5 \mathrm{~mm}$ wavelengths, is largely a function of the surface texture of aggregate particles. Microtexture affects the adhesion area between aggregate and the mobile element that contacts it (tire rubber in case of vehicular traffic and the shoe lower surface in the case of pedestrian mobility) and controls the pavement friction level at low speeds.

In pavement engineering, a number of devices have been developed to measure and characterize pavement surface friction.

In order to measure the skid resistance related to surface microtexture and to assess how it is affected by the material in contact with the pavement surface, a specific experimental activity using the British Pendulum Tester at Road Research Laboratory of the University of Pisa was organized.

The British Pendulum Tester (BPT) is a dynamic pendulum impact-type tester used to measure the energy loss when a rubber slider edge is propelled over a test surface. The results are reported as British Pendulum Numbers (BPNs) to emphasize that they are specific to this tester. The method is based on a swinging, dummy heel (using a standardized rubber soling sample), which sweeps over a set area of a testing surface in a controlled manner. The slipperiness of the surface (road pavement, flooring) has a direct and measurable effect on the pendulum value given [15].

A rock type, extensively present in the hills around Volterra and widely utilized for road pavements in Volterra, has been taken into account: the panchina volterrana. Two test-pieces have been characterized: the first one includes widely sea salt and fossils that give it a bluegrey color (type 1); the second one is characterized by a minor presence of sea salt and fossils and is called 'sabbione' (type 2). For each test-piece, we tested two different finishing surfaces: flat and chiseled. The four test surfaces are shown in Fig. 2. 

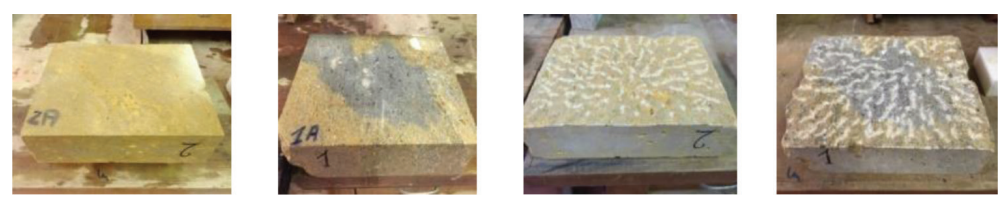

Figure 2: The four test surfaces.

Panchina volterrana (arenaceous limestone) was the main building material used in Volterra since the Etruscan era; from the Middle ages on, the use of panchina was the norm. From a stoneworking point of view, 'this stone is fairly submissive to iron when just excavated, and then hardens with time'. There were two ways to work it: one was rough-chiselling and leaving it just barely squared off, and the other more regular, which levelled and squared it off [16].

As finishing surfaces, the flat and the chiseled ones have been selected. The chiseled one has been selected because since the last two decades of the 19th century has been considered as a regular treatment of road pavement.

If panchina was constantly 're-chisel finished', 'it provides greater resistance and allows carts to travel over it without danger' [17].

Indeed, in the 1865, the city engineer, Gaetano Guerrieri maintained that 'since the piazza ramp and Via Ricciarelli have been re-chisel finished, even loaded carts are allowed to use them' [17].

The chiseled finishing surface has been provided by the technician that is currently in charge of this task for the municipality of Volterra. The polished finishing surface has not been taken into account in these experiments because of a lack of time.

We took into consideration five different materials for the slider: rubber (as standard reference), fir wood, walnut wood, leather and steel. The wood slider refers to clogs, the leather slider refers to necked feet and leather shoe soles and the iron slider refers to stagecoach wheels.

Each experiment refers to a given test surface and a given slider; the target is to assess the related the skid resistance. In a given experiment: a test surface has been selected; a slider has been fixed to the pendulum; the slider has been propelled over the test surface and the given BPN has been read. This last part of the experiment has been repeated six times and we considered as final BPN for the given experiment, the average value of the BPNs resulting from the six runs.

All the experiments have been repeated in dry and wet conditions.

We therefore performed 40 experiments: changing the slider (rubber, two types of wood, leather and steel), changing the finishing surface of the test stone (flat and chiseled), changing the test-piece (types 1 and 2) and finally changing the experiment conditions (wet and dry).

The BPNs for all the experiments are shown in Table 1 . The first table refers to the flat finishing surfaces and the second table refers to the chiseled finishing surfaces. In the tables, condition 1 refers to the test surface material of type 1 and condition 2 to the test surface material of type 2 .

The data of Table 1 have been plotted in Fig. 3 for a comparison. The y axis refers to the BP numbers, the $\mathrm{x}$ axis to the experiments. The data in light blue refer to the type 1 test-piece; the data in red to the type 2 test-piece. Dry-F refers to experiments in dry conditions and with flat finishing surfaces; Wet-F to wet conditions and again flat finishing surfaces; Dry-C to dry conditions and chiseled finishing surfaces and finally Wet-C to wet conditions and chiseled finishing surfaces. 
Table 1: Experimental results.

\begin{tabular}{|c|c|c|c|c|c|c|c|c|c|c|}
\hline \multicolumn{11}{|c|}{ Flat samples } \\
\hline \multirow{2}{*}{$\begin{array}{l}\text { Sliders } \\
\text { Conditions }\end{array}$} & \multicolumn{2}{|c|}{$\begin{array}{l}\text { EN Standard } \\
\text { Rubber Slider }\end{array}$} & \multicolumn{2}{|c|}{ Steel Slider } & \multicolumn{2}{|c|}{$\begin{array}{l}\text { Leather } \\
\text { Slider }\end{array}$} & \multicolumn{2}{|c|}{ Fir Slider } & \multicolumn{2}{|c|}{ Walnut Slider } \\
\hline & Dry & Wet & Dry & Wet & Dry & Wet & Dry & Wet & Dry & Wet \\
\hline 1 & 72 & 63 & 54 & 62 & 55 & 51 & 49 & 41 & 45 & 34 \\
\hline 2 & 79 & 70 & 54 & 58 & 55 & 56 & 47 & 38 & 44 & 33 \\
\hline \multicolumn{11}{|c|}{ Chiselled samples } \\
\hline Sliders & \multicolumn{2}{|c|}{$\begin{array}{l}\text { EN Standard } \\
\text { Rubber Slider }\end{array}$} & \multicolumn{2}{|c|}{ Steel Slider } & \multicolumn{2}{|c|}{$\begin{array}{l}\text { Leather } \\
\text { Slider }\end{array}$} & \multicolumn{2}{|c|}{ Fir Slider } & \multicolumn{2}{|c|}{ Walnut Slider } \\
\hline Conditions & Dry & Wet & Dry & Wet & Dry & Wet & Dry & Wet & Dry & Wet \\
\hline 1 & 91 & 82 & 73 & 68 & 55 & 47 & 59 & 45 & 63 & 40 \\
\hline 2 & 78 & 70 & 67 & 72 & 50 & 43 & 51 & 42 & 50 & 44 \\
\hline
\end{tabular}

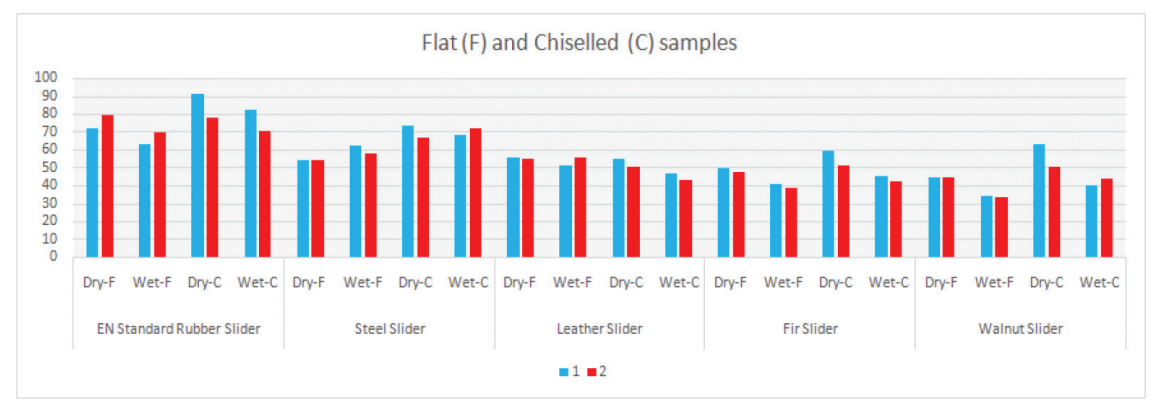

Figure 3: The BPNs resulting from the experiments.

Looking at the pavement materials, type 1 test-piece provides a slight better skid resistance than type 2 in most of the situations. However, both the materials result suitable for road pavements, since the minimum acceptable threshold according to Norme EN $(1,342)$ is 35 BPN for road pavements in outdoor pedestrian areas [18].

Looking at the finishing surface, the chiseled one provides a better skid resistance than the flat surface in most of the cases. The advantage of the chiseled finishing surface disappears only in the case of a leather slider and, conversely, is more evident in the cases of wood sliders.

A poorer skid resistance results in the cases of wood sliders, even worst in wet conditions. If we assimilate the wet condition in the experiments to the mud that usually covered the road pavement in the past, it results evident the critical role of chiseling for improving the skid resistance related to wood shoes on stone pavements. The chiseling process was therefore critical for ensuring safety for pedestrian mobility. 


\section{CONCLUSIONS}

The paper explored safety for pedestrian mobility in the present and in the past. With reference to stone pavements, it analyzed skid resistance as a function of road pavement microtexture and of the material of shoes soles. Friction in dry and wet conditions has been analyzed taking into account different types of shoes, used both in the past and in the present time.

Experiments have been carried out in the Laboratory of University of Pisa. The collected empirical data show the critical rule of the road pavement chiseling process in improving skid resistance and therefore safety on historical stone pavements. This is in line with the historical rules of road maintenance.

The actual mobility materials allow better skid resistance. However, given the wide dimension of stone slabs of road pavements, the border effects are neglectable and poor is the resulting grip. The grip decreases even more if the usage polishes the microtexture of the road surface. In this case, the chiseling process results very useful even in the present time.

The chiseled surface treatment is less resource consuming now than in the past since the polishing effect due to the mobility material is less critical now than in the past.

In order to guarantee mobility safety in historical city centers, it is very important to control the changes of the pavement surface macrotexture in time. This control allows to chisel the pavement stone surface when it is required. Advanced tools like laser Line-Scan cameras, more and more used to automatically detect and classify pavement surface distresses, can be also routinely used to monitor texture changes of stone slabs [19].

\section{ACKNOWLEDGEMENTS}

The research has been funded by the University of Pisa. The authors are specifically grateful to: the master mason Giorgio Scarselli, who continues to preserve the Volterra's stones; the Volterra City Council for logistical support. Francesco Puccinelli for his support in carrying out the experiments in the laboratory.

Author's contribution to the paper: Denise Ulivieri wrote chapter 2 and chapter 3; Elvezia Cepolina and Alessandro Marradi wrote chapter 4.

\section{REFERENCES}

[1] Vasari, G., Le Vite de' più eccellenti Pittori Scultori ed Architettori, eds. G. Milanesi \& I, Lorenzo, Torrentino: Firenze, p. 283, 1878.

[2] Palladio, A., I quattro libri dell'architettura, eds. L. Magagnato \& P. Marini, Libro III, cap. II, Il Polifilo: Milano, pp. 192-194, 1980.

[3] Alberti, L.B., L'architettura [De re aedificatoria], ed. G. Orlandi, Lib. IV, cap. VI, Il Polifilo: Milano, pp. 320-322, 1966.

[4] Baldinucci, F., Vocabolario toscano dell'Arte del Disegno, Per Santi Franchi al Segno della Passione: Firenze, 1681, available at http://baldinucci.sns.it/html/index.html

[5] Vivoli, C., "Provisione et ordini concernenti la iuriditione, et obligho delli ufitiali de' fiumi, et lor ministri". La Legislazione medicea in materia di strade, ponti e fiumi. In $L a$ legislazione medicea sull'ambiente. Scritti per un commento, eds. G. Cascio Pratilli \& L. Zangheri, IV, Leo S. Olschki: Firenze, p. 76, 1998.

[6] Lenzi, A., Dalla Repubblica fiorentina al Granducato mediceo. Dal "cotto" alla "pietra forte". In Firenze, la materia della città. Materia e disegno pavimentale nelle strade del centro storico, ed. F. Gurrieri, Edizioni Polistampa: Firenze, pp. 61-62, 2012.

[7] Weller, J.A., Roman traction systems, available at http://www.humanist.de/rome/rts/ wagon.html 
242 Urban Regeneration and Sustainability

[8] Johnston, R.A., All Things Medieval: An Encyclopedia of the Medieval World, 2 vol., Greenwood: Santa Barbara, 2011.

[9] Riello, G. \& McNeil, P., Camminando per le strade del Settecento: la scarpa nel secolo del Lumi. In Scarpe. Dal sandalo antico alla calzatura d'alta moda, eds. G. Riello \& P. McNeil, Angelo Colla Editore: Vicenza, pp. 67-79, 2007.

[10] Muzzarelli, M.G., Scarpe suntuose: produrre e calzare nell'Italia medievale, In Scarpe. Dal sandalo antico alla calzatura d'alta moda, eds. G. Riello \& P. McNeil, Angelo Colla Editore: Vicenza, pp. 37-53, 2007.

[11] Vianello, A., Donna cortese o cortigiana? L'uso delle pianele nella Venezia del Rinascimento. In Scarpe. Dal sandalo antico alla calzatura d'alta moda, eds. G. Riello \& P. M cNeil, Angelo Colla Editore: Vicenza, pp. 55-65, 2007.

[12] Muzzarelli, M.G., "De ornatu mulierum". Il caso delle pianelle. In Dai cantieri della storia. Liber amicorum per Paolo Prodi, eds. G.P. Brizzi \& G. Olmi, CLUEB: Bologna, pp. 435-444, 2007.

[13] Cantini, L., Legislazione toscana raccolta ed illustrata dal Dottore Lorenzo Cantini, 1800-1808, ed. M. Montorzi, ETS: Pisa, pp. 93-147, 2006.

[14] Lu, Q. \& Steven, B., Friction testing of pavement preservation treatments: literature review. Technical Memorandum: UCPRC-TM-2006-10, Department of Transportation: California, 2006.

[15] Marradi, A., Secchiari, L. \& Lezzerini, M., I materiali lapidei versiliesi. La qualificazione per l'utilizzo nei sistemi di pavimentazione, Alinea editrice: Firenze, pp. 43-52, 2012.

[16] Trinciarelli, V. \& Marrucci, A., Le rocce del volterrano, Consorzio di gestione Museo e Biblioteca Garnacci: Volterra, pp. 66-72, 1990.

[17] Post-Unification Historical Archives of Volterra, Vie Comunali, Manutenzione.

[18] Domenichini, L. \& Martinelli, F., Proprietà estetiche e funzionali delle pavimentazioni stradali in ambito urbano. Proceeding of the Convegno Nazionale, La sicurezza sulle strade della città, "Andare a scuola: ciclisti e pedoni", Lucca, 2006.

[19] Marradi, A., Drenth, K. \& Stonecliffe-Jones, M., Automatic detection and analysis of surface distresses using a multi functional vehicle in International Journal of Pavement Engineering and Asphalt Technology, 13(2), 2012. 